\title{
Effects of Human Activities on Zambia's Kafue Flats Ecosystems
}

\author{
by
}

\author{
Walter A. ShePpe, Ph.D. (British Columbia) \\ Professor of Biology, University of Akron,
}

Akron, Ohio 44325, USA.

\section{INTRODUCTION}

In May 1967, on the edge of Zambia's Kafue Flats, the extensive annual floods were largely hidden by a dense growth of emergent grasses reaching to the horizon. Large herds of Lechwe (Kobus leche) grazed on the higher ground around the floodplain and out into the shallow floodwaters. Smaller numbers of Zebra (Equus burchelli), Wildebeest (Connochaetes taurinus), and other ungulates, fed on the high ground. One of the world's greatest agglomerations of avian biomass occupied the floodwaters and the shore (Fig. 1). cover of low grasses and was being invaded by woody plants. There were few birds, relatively few Lechwe, and no other large ungulates (Fig. 2).

These changes and others in the Kafue River basin are the result of a variety of natural or human influences, the most important of which was the construction of hydroelectric dams on the Kafue above and below the Flats. These influences have already caused marked environmental changes and their long-term effect may be to destroy much of the rich variety of communities that once occurred along the River.

This report is based on a twelve-months' study in 1967-

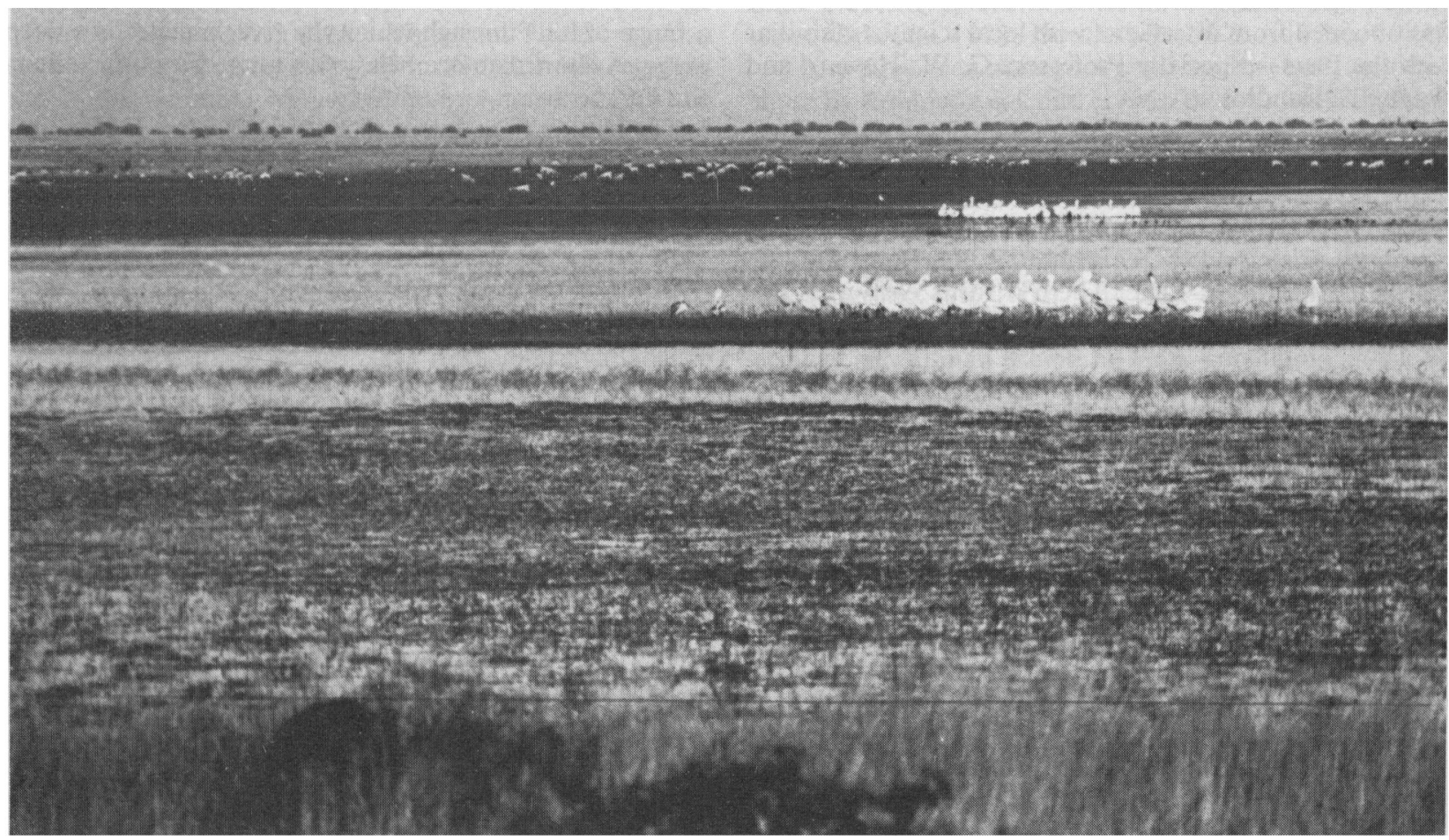

Fig. 1. The edge of the high flood in Lochinvar National Park in May 1967, before construction of the dams. Plentiful Lechwe are feeding in the background on emergent floodplain vegetation and numbers of White Pelicans (Pelecanus onocrotalus) and other large birds are in evidence.

In May 1983, at the same place, the lower elevations on the floodplain were covered by permanent open water, and the higher elevations were perhaps permanently dry. The very productive vegetation that had depended on annual flooding had been largely replaced by aquatic plants in the open water, while the dry former floodplain had a sparse
68 , brief visits in 1970 and 1971 , and a six-weeks' visit in May-July 1983 . The primary purpose of the 1983 visit was to compare conditions at that time with those prevailing before the dams were built. In 1983, various parts of the Flats were observed from the air and ground, and small mammals were trapped in Lochinvar and Kafue National 


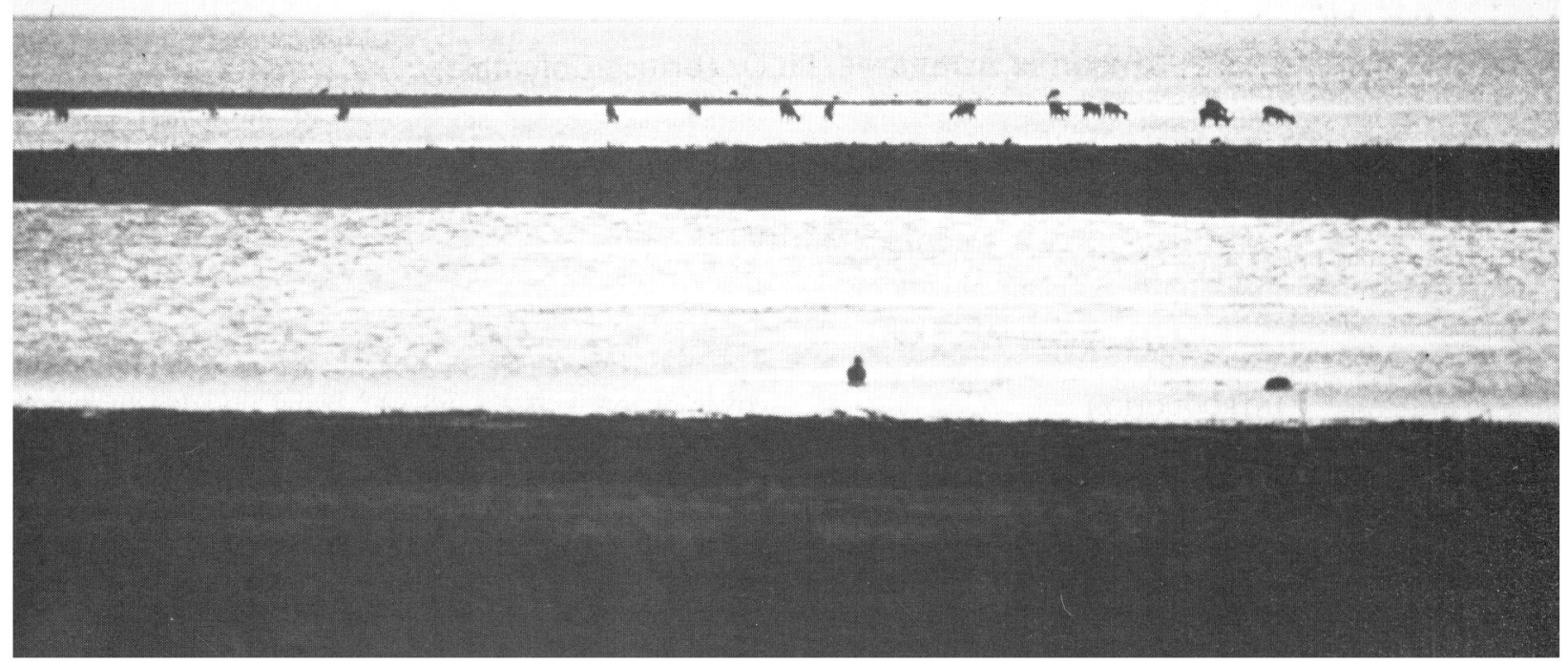

FIG. 2. The same site as Fig. I but in May 1983. The permanent Chunga Lake is now part of the reservoir of the Gorge Dam. Its water-level fluctuates somewhat with the flooding of Kafue River, and at high-flood a month earlier the exposed mud-bars were under water. There are few Lechwe and birds, and no emergent vegetation was seen.

Parks (Fig. 3). Much information on the effects of the dams was obtained from interviews with local scientists familiar with the Flats-especially Professors G. W. Howard and Wayne L. Handlos.

\section{The Kafue Basin}

The Kafue River is one of the main tributaries of the Zambezi, arising on the Zaire border and flowing southwards to Itezhitezhi Lake. There it turns eastwards and flows across the broad Kafue Flats, which ends abruptly at a range of hills through which the river plunges in a deep gorge. A short distance below this gorge the Kafue enters the Zambezi.

The Flats is a floodplain of about $6,000 \mathrm{~km}^{2}, 235 \mathrm{~km}$ long and up to $40 \mathrm{~km}$ wide (Fig. 3). The River meanders through it at a very low gradient for a length of about $410 \mathrm{~km}$. The life of the Flats is dominated by the alternating wet and dry seasons, and by the annual floods (W. L. Handlos, 1982). The long-term mean rainfall at peripheral stations ranges

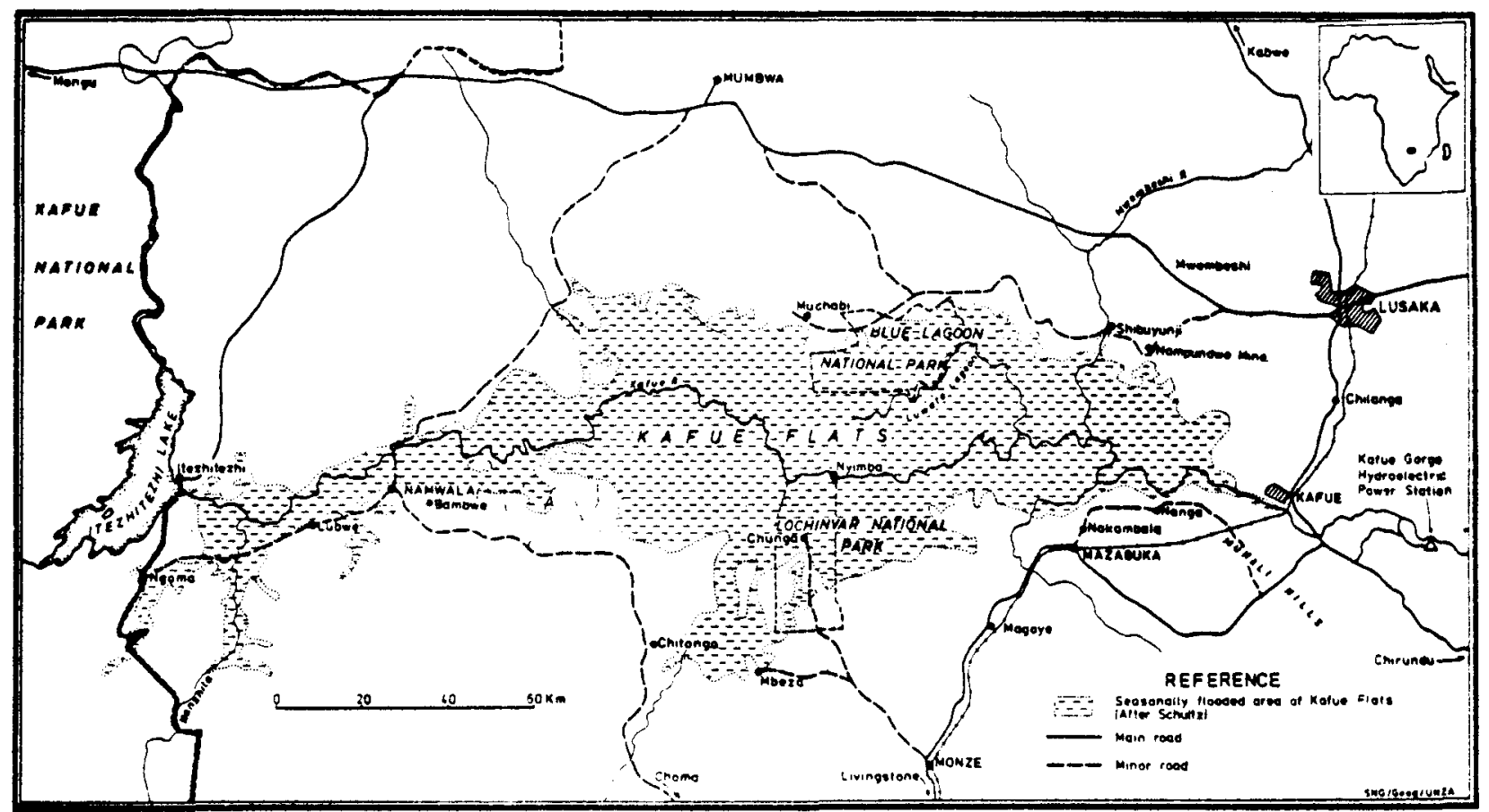

FiG. 3. Map of the Kafue Flats (modified from Howard \& Williams, 1982). Inset maplet above on right shows position in Africa. 
from $77 \mathrm{~cm}$ to $90 \mathrm{~cm}$ annually, with the rains usually beginning in November and ending in April.

Parts of the Flats are shallowly flooded early in the rains-from local rainfall and runoff, though the major flooding is from the River, by water from the wetter, northern part of the basin. Before the dams were built the River level began to rise slowly in December and reached its crest after the end of the rains-typically in May, when most of the floodplain was under several metres of water. The level then dropped slowly until the next flood began. At low water, most of the floodplain was dry, with permanent water only in the River channel and in various oxbows and lagoons.

Because of this flood regime, the Flats was alternately a large lake and a dry grassland. The floods excluded almost all trees, and the vegetation was largely of grasses - most notably Echinochloa stagnina, Oryza longistaminata, and Phragmites mauritianus. The grasses usually grew rapidly enough to remain above the slowly rising water-level. Because of the abundant water, the floodplain vegetation was the most productive in the region, supporting large populations of a variety of animals.

Lechwe were the most abundant ungulates using the floodplain, with smaller numbers of Zebra, Wildebeest, and other species in some places. Hippopotamus (Hippopotamus amphibius) and Crocodiles (Crocodylus niloticus) lived in and around the water, and there were Sitatunga (Tragelaphus spekei) in dense vegetation. There were also several kinds of carnivores and small mammals, notably the Multimammate Mouse (Praomys natalensis). Most animals moved off the floodplain as the floods rose, and later followed the receding flood back onto the floodplain (Sheppe \& Osborne, 1971).

Lechwe are floodplain animals, and a major reason for their success is that they are the only ungulate on the Flats that feed in the shallow floodwaters, using the flooded grasses while they are still most nutritious (Rees, 1978a). The slowly-receding flood makes fresh food available to them and other species during much of the dry season.

Over 400 species of birds are known from the Flats, including about 125 waterbirds (Douthwaite, 1982) involving a large variety of ducks, geese, herons, egrets, shorebirds, pelicans, storks, ibises, and cranes. The Flats had the world's largest population of Wattled Cranes (Grus carunculatus), while Fish Eagles (Haliaeetus vocifer); Darters (Anhinga rufa), and Jacanas (Actophilornis africanus), were common.

The Flats supported a large fishery, based primarily on the productivity of the floodplain. During the floods the fish moved onto the floodplain and apparently most spawning and growth took place there. Many species were caught - primarily various cichlids (Sartherodon spp. and others) and barbels (Clarias spp.).

At one time Lechwe and other ungulates seem to have been abundant over much of the Flats, but in this century their numbers have become greatly reduced by over-hunting and they are now confined to relatively small areas, particularly on and around Lochinvar and Blue Lagoon National Parks near the middle of the Flats. Most animals were probably always restricted in distribution by the occurrence of suitable habitats. There was also great seasonal variation associated with changes in plant cover and flooding, while many of the birds were migratory, spending only part of the year in Zambia.

The situation was further complicated by marked yearto-year variation caused largely by differences in the amount and timing of rainfall and flooding. Both plant growth and the relative importance of different plants varied greatly from year to year, so that different workers described the vegetation quite differently. Because of this variation from place to place and time to time under natural conditions, it is difficult to draw precise conclusions about the effects of subsequent environmental modifications by people.

\section{Previous Studies of the Flats}

The Kafue Flats ecosystems have been extensively studied both before and after construction of the dams. In the 1960s, an FAO team produced a multivolume report on the resources of the area (FAO, 1968). The all-important hydrology of the Flats was studied by the FAO team and more recently by a Dutch team (DHV Consulting Engineers, 1980). Soils and agriculture were studied by FAO.

FAO (1968), Douthwaite \& Lavieren (1977), and others, have described the vegetation. The fish and fisheries have been studied by Chapman et al. (1971), Lagler et al. (1971), Dudley \& Scully (1980), and Muyanga \& Chipundu (1982), among others. Several workers have studied bird populations (Osborne, 1973; Douthwaite, 1974a, 1974b, 1982).

There have been numerous studies of Lechwe, including those by Robinette \& Child (1964), Bell et al. (1973), Sayer \& Lavieren (1975), D. M. Handlos et al. (1976), Schuster (1976), Rees (1978a, 1978b), and Howard \& Jeffery (1981, 1983). Other mammals have received less attention (Sheppe \& Osborne, 1971; Sheppe, 1972, 1973).

The University of Zambia has had an active interest in the area since the 1960s, and its Kafue Basin Research Project (KBRP) continues to study some aspects of the ecology and human use of the Flats-including an annual aerial census of Lechwe populations. KBRP has also sponsored several conferences and publications on the area (Williams \& Howard, 1977; Howard \& Williams, 1982).

In spite of all these studies, two facts stand out. First, our understanding of the basin is still inadequate for satisfactory protection and management of its resources and, second, what we do know has had little effect on policy decisions. The construction of the power project was approved without regard to its probable environmental effects, and its design and operation have been based almost entirely on a desire to produce the greatest possible amount of power-without regard to other interests.

\section{The Changing Basin}

The basin is changing in response to a variety of forces. Some of these will be discussed here, with emphasis on the Flats and especially on Lochinvar National Park, which is the best-known part of the Flats.

\section{Water Supply}

In spite of the dramatic floods, a shortage of water is a major constraint on future development of the basin. 
Water is needed to maintain natural ecosystems, for power generation, for irrigation, and for urban/industrial use; but there is not nearly enough of it to meet the potential demand for all these uses.

Much water is lost by evapotranspiration from the flooded Flats and from the Lukanga Swamp higher up in the basin. This loss is unavoidable if the integrity of the ecosystems is to be maintained; but people who have other uses for the water, talk of reducing this loss by directing the water along routes with less surface area and emergent vegetation. Canals have been suggested to bypass many of the River's meanders on the Flats, though it seems that this would be prohibitively expensive. Parts of the Flats could also be diked to exclude flood-waters.

Power officials want to maximize power production by running as much of the River's flow as possible through their turbines. This is basically a non-consumptive use, allowing the water to be available for use downstream, but on the Kafue there is little opportunity to use the water that is released from the Gorge power-plant, because the towns and most of the land that is suitable for irrigation are above the Gorge.

Zambia badly needs to increase its agricultural productivity, and there would be good potential for development of irrigated agriculture on and around the Flats if only water were available. This could only be done at the cost of reduced power production, and so it seems clear that conflicts over water-rights will increase in the future.

\section{Wildlife}

Both the numbers and the distribution of large mammals on the Flats have been greatly reduced during this century. Lechwe, always the most abundant species, are now confined largely to the vicinity of Lochinvar and Blue Lagoon National Parks and the area between (Fig. 3). The Lechwe population declined from an unknown very large number in 1930 to about 80,000 in 1975 . Aerial censuses gave estimates of about 45,000 in 1981 and about 41,000 in 1982 and 1983 (Howard \& Jeffery, 1983). These most recent counts suggest that the numbers may be stable at present.

Populations of other large mammals are less well known. There still are numbers of Zebra and a small herd of African Buffalo (Syncerus caffer) on the floodplain in the Blue Lagoon area, while in the Lochinvar area there are Zebra and Wildebeest. In recent years a small population of Eland (Taurotragus oryx) has disappeared from Lochinvar, either by poaching or by moving out of the area, and a small herd of African Buffalo has moved into the area. Almost all large predators were extirpated during the days of commercial ranching in order to protect the cattle.

There have been no recent quantitative studies of bird populations, but they seem to have declined.

\section{Hunting}

In the past, hunting was the major human influence on the large mammals of the Flats, and was primarily responsible for their decline in numbers and distribution. Most of the decline in Lechwe numbers was caused by organized mass hunts by local people that continued until 1957. Since then, illegal hunting has continued at a variable but unknown rate and probably has caused most of the subsequent decline.

The apparent stability of the Lechwe population in the past few years suggests that poaching may now be under control; but if this is so, it is hard to see how. Law enforcement is not vigorous, and the occasional poachers who are arrested are dealt with leniently.

In recent years a sizeable sport-hunting business has developed in the Lochinvar area, primarily catering to foreign hunters who fly in to add Lechwe to their life-list of animals killed. The impact of this hunting is not known, but it seems that too few animals are killed in this way to threaten an otherwise healthy population.

\section{Human Presence}

Wildlife can be threatened by the mere presence of people if this causes the animals to change their movements and behaviour. At Lochinvar the main route north to the River crosses areas which are heavily used by Lechwe at some seasons, and every passage of a vehicle disturbs the herds. Fishermen, fish traders, tourists, hunters, poachers, park and fisheries staff, and biologists-all contribute to the disturbance, and the amount of it is increasing. But, so far, there is no clear evidence that this is having a significant impact on the herds.

\section{Fishing}

There has long been a major fishery on the Flats, supported by the high fish-productivity of the floodplain. The fishermen operate largely from small villages situated along the River, mainly using gill-nets. The once-ubiquitous wooden dugout canoes are rapidly being replaced by much-superior fibreglass boats. The fish are either dried or carried fresh daily to city markets by fish traders.

The status of the fishery is changing rapidly because of the dams and the changing intensity and kind of fishing pressure. The dams altered the flooding schedule and the vegetation - undoubtedly with effects on the fish populations.

A good market for fish has caused many fishermen to move into the area from other parts of the country. They have introduced the use of small-mesh gill-nets that kill many fish which are too small to be marketed. They drive fish into the nets by hitting the water surface with paddles-practices which are illegal but cannot be stopped.

These practices, combined with the increased number of fishermen, have greatly reduced fish populations on the eastern part of the Flats, threatening the future of the fishery. This is a serious problem, because fish is a major food in Zambia and the fishery provides many jobs. Efforts to establish stable fishing communities, with land tenure for individual fishermen and at least a minimum of social services, have been largely unsuccessful, because of the uncontrollable movement of people into the communities.

At one time fishermen were largely excluded from Lochinvar National Park, but now the northern part of the floodplain there is heavily used by fishermen from nearby villages, while fish traders drive through the Park to reach 
the fishermen. The southern part of Chunga Lake in the Park is supposed to be closed to fishing, but Park and fisheries personnel are on friendly terms with the fishermen and seem to make no effort to enforce this rule.

\section{Cattle}

The floodplain has no human settlements except small fishing villages along the River. The Tonga people to the south, and the Ila in the west, are herdsmen, and wealth is measured by the number of cattle owned. The herds are genetically diverse and often in poor physical condition.

The dry season is especially hard on the cattle in the woodlands, and they often lose much weight at that time. Some of the herdsmen traditionally trek their cattle across the floodplain to the River after the floods recede, giving them access to abundant water and better grazing than is available in the woodlands at that season.

When Lochinvar Ranch was established by European settlers around the beginning of the century, the cattle of the local people were excluded from grazing there. Now the people are illegally bringing their cattle back into the open woodlands in the southern part of the Park, causing serious damage to the vegetation and soil in some places in which the grass has been destroyed and the soil trampled into a fine powder that blows away with the wind. Moreover, stream-banks are eroded away at cattle access points.

There are always cattle grazing close to Park headquarters and outlying game-scout camps, and pressure from the herdsmen is too great to be effectively resisted by the Park authorities with their limited resources. Occasionally, cattle are impounded and held until the owner pays a token fine (for 20 head about US \$2.55); but this does not seem to serve as an effective deterrent.

\section{Agriculture}

The largest agricultural project in the area is the Nakambala Sugar Estate on the south-east edge of the Flats, just off the floodplain. It was first developed in the 1960s and now occupies some 10,300 ha. It depends largely on irrigation water brought by canals from the Kafue, and its future development is limited primarily by the amount of water that is available.

There has long been interest in growing crops on the floodplain itself. This would require control of waterlevels, heavy use of fertilizers, and special techniques for cultivating the heavy, black, cracking clay soils. Pilot work has shown that a good yield can be obtained with a number of crops. This is not now being implemented, howeverprimarily because of a lack of water for irrigation.

\section{Drought}

Rainfall was very low in the 1981-82 and 1982-83 seasons, when it amounted to about half of the long-term average. Because of this, crop yields were very low generally in Zambia, and some rural water-supplies failed. Plant growth on most of the Kafue floodplain was much reduced, and extensive areas that usually would have had a luxuriant growth of grasses at the end of the rains had only a sparse

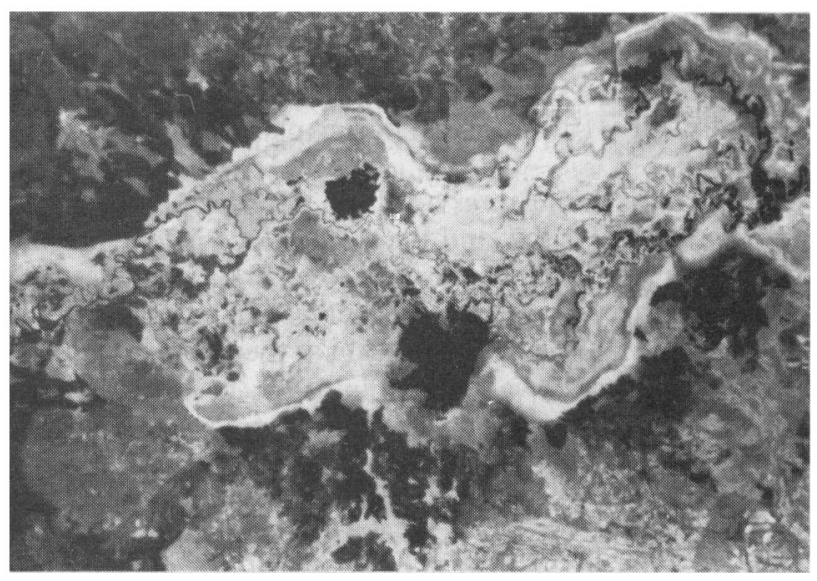

FIG. 4. Landsat image of the central Kafue Flats on 15 August 1981. The light-coloured area in the centre is floodplain and the darker areas to the north and south are mixed grassland and open woodland. The flood has receded and most of the floodplain is dry. The largest body of water (dark, near centre) is Chunga Lake-former floodplain that is now permanently under water. Lochinvar $\mathrm{Na}$ tional Park is in the lower centre and Blue Lagoon National Park in the upper right-hand corner.

'stubble' in May 1983. It is not clear how much the drought reduced river-flow, because rainfall was nearly normal in the upper basin where most of the flow originates.

\section{Dams}

By far the most important influence on the Flats has resulted from the construction of power-dams on the Kafue immediately above and below the floodplain. The primary dam is below the floodplain in the upper Gorge; completed in 1972, it has a capacity of $900 \mathrm{MW}$ and a firm annual output of over 5,000 gigawatt hours (Balasubrahmanyam \& Abou-Zeid, 1982).

Power production is a function of the volume of water and the vertical distance from the surface of the reservoir to the turbines (head). The Gorge Dam produces a large amount of power from a relatively small volume of water,

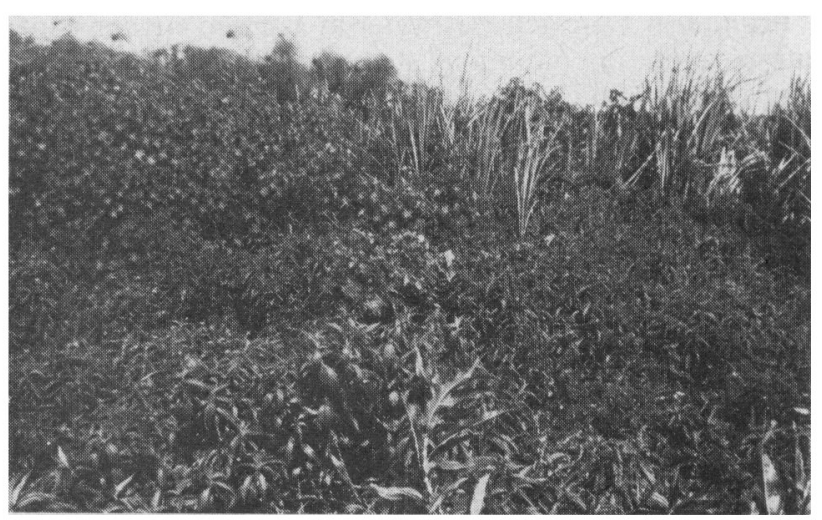

FIG. 5. A recently-formed 'thicket' of Papyrus, cattails, Polygonum $s p$., and other plants, on the edge of Chunga Lake where formerly there was open grassland. Such growths support populations of small mammals that appears to be permanent. 
by taking advantage of the rapid drop of the River in the Gorge to give a large head. Water from the reservoir is carried through a headrace tunnel for $10 \mathrm{~km}$ and then falls vertically for $410 \mathrm{~m}$ to the power-plant just above the River.

Most of this dam's reservoir is on the floodplain, so that storage capacity is low and the surface area is large, resulting in a large evaporative water-loss. In order to get sufficient storage without a great increase in surface-area, a second dam was built at Itezhitezhi at the upper end of the Flats (Fig. 3), and was closed in 1977. It forms a large reservoir that provides most of the system's storage capacity. Power production can be increased in the future by installing generators at Itezhitezhi and constructing a second power-plant lower in the Gorge.

This project, combined with power from Victoria Falls and Zambia's share of the power from Kariba Dam on the Zambezi, gives Zambia a surplus of power above its present needs. This surplus is sold to Zimbabwe, and in the present depressed condition of the world copper market it is Zambia's principal source of foreign exchange.

These dams have had severe environmental impacts on the floodplain and on the Kafue above and below the project. The primary effect on the floodplain has been to reduce very markedly the amount of land that is seasonally flooded. Much of the eastern part of the floodplain is now permanently under water, which extends at lower elevations as far west as the central part of the Flats in Lochinvar National Park (Fig. 4), where Chunga Lake now occupies what was once floodplain.

\section{Vegetation}

The floodplain vegetation, mostly consisting of grasses, depends on the annual flooding-cycle and has died out in the new bodies of permanent water, which in places now support large submerged mats of aquatic vegetation. Lagarosiphon ilicifolius and Potamogeton thunbergii have been identified from Chunga Lake.

Thickets of plants that require permanently moist soil are becoming established along the shore of the new bodies of water (Fig. 5). These plants include Papyrus (Cyperus papyrus) and Cattail (Typha domingensis), which formerly were excluded by the dry soil that prevailed during the low-water season.

Itezhitezhi Dam releases water at a relatively constant rate to assure a continuous supply at the Gorge powerplant, thus greatly reducing the seasonal fluctuation in the volume of water on the Flats and consequently reducing the height and extent of the floods. Much former floodplain, primarily in the western part of the Flats, is no longer flooded.

During a 'normal' year, before the dam was built, flow in the western Flats ranged from 30 to 1,400 cumec (cubic metres per second), with recorded extremes of 10 and 2,700 cumec (DHV Consulting Engineers, 1980). In an effort to produce some semblance of an annual flood, 300 cumec is now released briefly each March; but this rate seems trivial in comparison to the 'normal' maximum of $1,400 \mathrm{cu}-$ mec.

As had been expected, the elimination of floods on much of the Flats has reduced the productivity of the grasses there, though in 1983 it was not possible to distinguish this

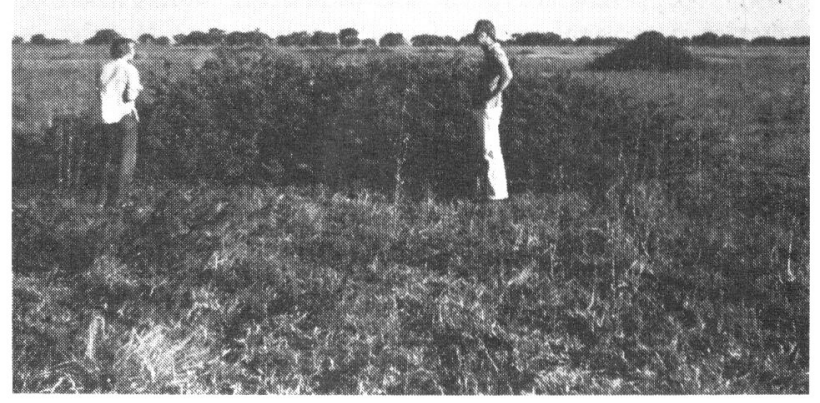

FIG. 6. Thickets of Mimosa pigra on former floodplain that is now permanently dry.

effect from the effect of the drought. Flood elimination has also permitted the invasion of the floodplain by woody plants that formerly were killed by the floods. The most common is Mimosa pigra, a tropical American shrub that is now a pest in many tropical areas around the world (Fig. 6). Hibiscus diversifolius var. rivularis also occurs in places. Only a very small area is occupied by such plants as yet, but they are spreading.

\section{Other Effects}

Unidentified ants are now widespread in places where formerly they did not occur (Sheppe \& Osborne, 1971). Surprisingly, termite mounds were not seen on the former floodplain, although, before the dams were built, colonies were sometimes temporarily established in sites that were not flooded during years of low floods.

It had been expected that the dams would benefit the fishery, but initially at least this does not seem to have happened (Dudley \& Scully, 1980). Experimental sampling in the mid-1970s showed reduced populations of several major fish species, although it is not clear whether this is a long-term trend and, if so, whether it is caused by the dams, over-fishing, years of low rainfall, or yet something else.

T. O. Osborne (in litt.), former Park Biologist at Lochinvar National Park, on the basis of recent brief visits to the Flats, believes that the altered flooding regime has adversely affected ungulates, cattle, birds, and fish. Elimination from large areas of the former floodplain grasses has reduced the populations of herbivores and of their predators. The floodplain fish were primarily herbivores, and populations of both fish and fish-eating birds have been reduced. There are now many fewer of the formerly abundant herbivorous snails, and of the Openbill Storks (Anastomus lamelligerus) that fed on them. A reduction in herbivorous insects has also led to there being now smaller numbers of Jacanas and other insect-eating birds than formerly.

The Gorge Dam has affected the fishermen directly by eliminating large areas of the emergent floodplain vegetation that formerly protected the flood-waters from the wind. The open water that has replaced it is exposed to the wind and at times becomes quite rough. The fishermen are not accustomed to this and, being unable to swim, some of them have drowned when their boats capsized. In 1978 Itezhitezhi Dam threatened to leak, and so the water-level was rapidly lowered, thus creating sudden and unexpected 
flooding on the Flats that endangered fishermen and cattle.

Itezhitezhi Reservoir now covers what was formerly one of the most productive parts of Kafue National Park, including an extensive riverine grassland area that was known as Puku Flats (Fig. 7). The Puku (Kobus vardoni) that lived there have disappeared altogether from this part of the Park.

In the Gorge the River formerly fell over a long series of rapids, cascades, and falls, forming distinctive habitats and some of the most attractive scenery in Zambia. Now this water is bypassed through the headrace tunnel and the River in the upper Gorge is dry except occasionally when excess water is released from the dam directly into the River. Presumably* the biological communities of this section of River have been destroyed and the terrestrial wildlife that depended on the River for water has been affected.

The dams have been in place for only a few years, and their operation-most notably the schedule of water release - is still changing. No stable pattern of operation can be expected-because of variations in rainfall in the upper basin, fluctuations in power demand, and increasing experience $^{\dagger}$ with the system. The ecosystems are just beginning to become adapted to the hydrological changes produced by the dams.

These changes are still only poorly understood. The most fundamental data are the records of River level that are kept at a number of stations above, on, and below, the

\footnotetext{
* In answer to our query about this Professor Sheppe replied (in litt. 8 November 1984) “"Presumably..." should remain because no one has been in the Gorge to see what the present situation is (guarded by the army).'-Ed.
}

$\dagger$ In answer to our query the Author replied (Ibid.) 'I am sure that increasing experience will modify their practices, whether for better or worse no one knows.'-Ed.
Flats; but these records are incomplete and not entirely reliable. There are few useful data on the horizontal extent of the floods, while any discharge records for the dams have not been made available. Much of the Flats is for practical purposes physically inaccessible, and for security reasons no one is permitted to enter the Gorge.

Only casual observations have been made on changes in the vegetation and bird life. The numbers and distribution of the large mammals are changing, probably mainly because of changes in flooding and vegetation. Parts of the floodplain that once had only transient populations of rodents and shrews now have presumably permanent populations in the thickets of Papyrus and other plants that have developed on perennially-moist ground around new bodies of water. Specimens of the shrews Crocidura ?mariquensis and $C$. occidentalis, and of the rodents Praomys (Mastomys) natalensis complex and Dasymys incomtus, were trapped in such habitats in 1983. One specimen of the Black or Roof Rat, Rattus rattus, which had not previously been recorded from that part of Zambia, was trapped on the River bank opposite a fishing village.

The only animal that has been carefully monitored is the Lechwe, described above. Rees $(1978 a, 1978 b)$ believes that the altered flooding-regime threatens the Lechwe by reducing its food supply, while Schuster (1980) suggests that the altered regime may threaten the Lechwe directly by interfering with its reproductive behaviour and hence lowering the birth-rate.

Each species will be apt to respond to the changing flood regime differently, depending on how the precise details of the regime relate to its own needs. In the southern Everglades of Florida, man-made changes in the hydrologic regime have virtually eliminated successful nesting of Wood Stork (Mycteria americana), largely by interfering with its food supply (Kushlan et al., 1975). Similar responses can be expected in the closely-related Yellowbilled Stork (M. ibis) and other waterbirds of the Kafue Flats.

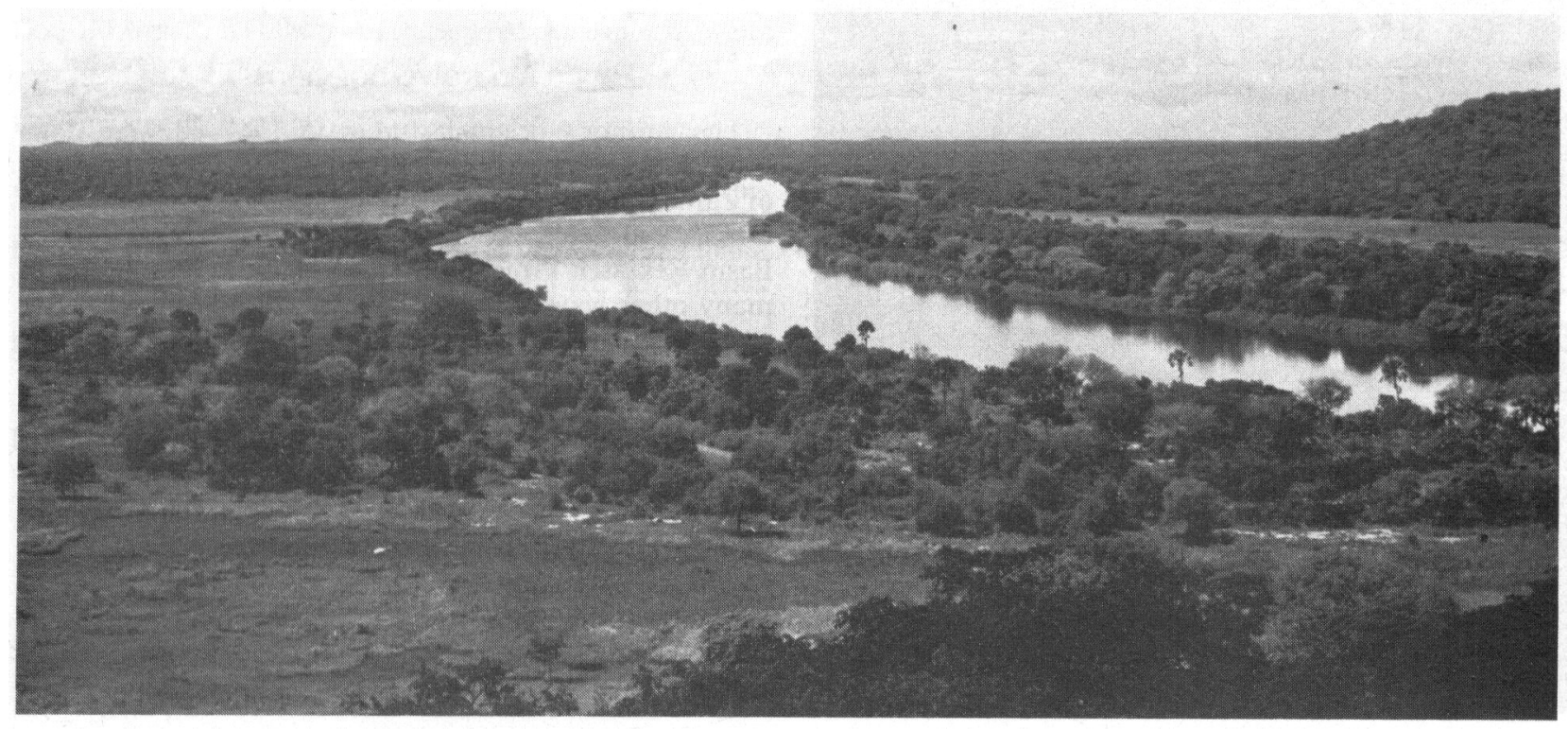

Fig. 7. Puku Flats, Kafue National Park, in December 1967, before construction of Itezhitezhi Dam. The area is now permanently under water [and so this and Fig. 8 constitue telling records of former attractions dissipated by Man-Ed.]. 


\section{The Future of the Kafue Flats}

The decision to build the dams on the Kafue River meant that the Flats would be irrevocably altered, and much of this change is already under way as had been foreseen. The extent and exact nature of the changes that occur in the future, however, will depend in part on decisions that have not yet been made concerning water-levels and land-use.

If the schedule of water release from the dams continues to be made with little regard for environmental consequences, we can expect severe effects. Some plants and animals will surely disappear from the Flats altogether, and the numbers of others will decline greatly. Total biological diversity may not decline as severely, however, as the newly-created aquatic and dryland habitats will be invaded by species that did not occur on the Flats before. The primary productivity of the new vegetation may be less than that of the formerly very productive floodplain grasses.

The best hope for preserving some semblance of the floodplain ecosystems would be to assure release of sufficient water from Itezhitezhi Dam to create extensive flooding. This release would have to be effected at the right season, at the right rate, and for a sufficient duration each time-all of which is unlikely to be done because it would not fit the demand for electric power, and because the power agency wants to minimize flooding in order to reduce water-loss by evaporation.

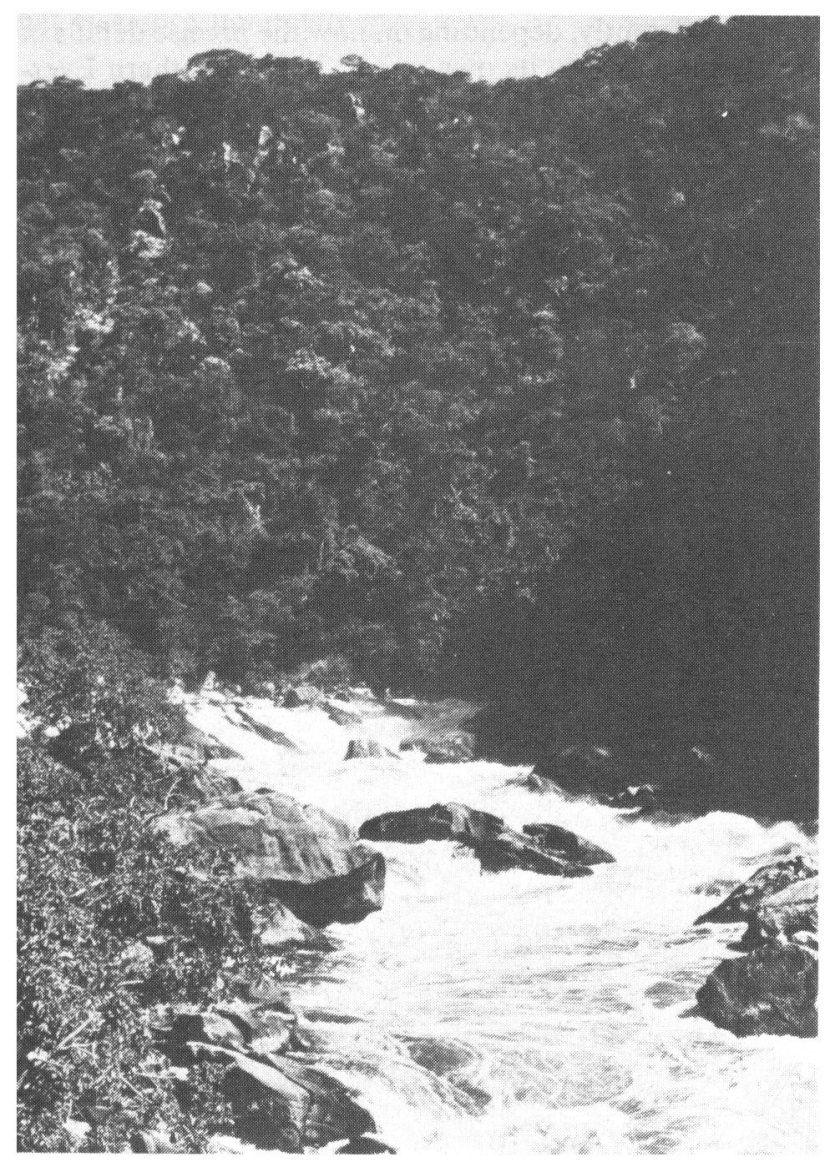

FIG. 8. The Kafue River in the Gorge in April 1967. This part of the river is now usually dry.
An alternative that would give a semi-natural flood regime would be to dike large areas of the central floodplain and control the water-level there by gates and perhaps pumps. The diked area could then be flooded even when the River level was low. Such a system would be expensive to construct, but operating costs should not be great. It would increase evaporative water-loss and so reduce potential power-generation.

Extensive agricultural development on the floodplain could also threaten natural ecosystems. This is not likely to be a serious problem, though, because there are large areas of floodplain which are suitable for development but have little wildlife, and also because a lack of water for irrigation would probably prevent any extensive agricultural development.

One of the most important properties of any ecosystem is its variability from year to year. Occasional extreme conditions may exclude long-lived species that cannot tolerate even one unfavourable year, but on the other hand variability of habitats may permit an increased variety of species to live in an area.

The effect of the dams will be to reduce the amount of year-to-year variation, and this will have important effects on the biotic communities. Variation will not be eliminated altogether, though, because of variation in local rainfall and because Itezhitezhi Reservoir is not large enough to compensate for all variations in runoff from the upper basin.

The future of the Flats will be determined by cabinetlevel decisions on national priorities. At present, power generation has an almost absolute priority; but changes in Zambia's economic situation may modify priorities in the future. Opposing pressures come from farmers, herdsmen, fishermen, tourism officials, and advocates of wildlife conservation. The wildlife advocates are still primarily expatriates, but the Wildlife Conservation Society of Zambia has an active programme for building interest in conservation among Zambian schoolchildren. Zambia is a oneparty state, and public opinion seems to have less influence on national policy than in many countries.

\section{ACKNOWLEDGEMENTS}

The Author's original studies in 1967-68 were done while he was Senior Lecturer in Zoology at the University of Zambia (UNZA). In 1983 he was a research affiliate of UNZA and Professor G. W. Howard, of UNZA's Kafue Basin Research Project, provided facilities and helped in many other ways. Professor Wayne Handlos, of UNZA, identified plants and helped in other ways, while Professor Andrew Siwela helped with arrangements, and Mr Davys Munachaka assisted in the field-work. The Zambian National Parks and Wildlife Service granted permission to work in the parks and provided other help. The field-work in 1983 was made possible in part by National Science Foundation Grant INT-8300437, and in part by a University of Akron Faculty Fellowship. All opinions expressed here are entirely the Author's.

\section{SUMMARY}

Hydroelectric dams have markedly altered the extensive floodplain of Zambia's Kafue River Flats. Before the dams 
were built in the $1970 \mathrm{~s}$, some $6,000 \mathrm{~km}^{2}$ of floodplain were under water for several months each year, permitting a dense growth of grasses and forbs that supported large populations of ungulates and waterbirds. Now a dam at the lower end of the Flats has permanently inundated parts of the floodplain, and a dam at the upper end has reduced the seasonal flooding, so that much of the floodplain is now probably permanently dry. When the Flats was revisited in 1983 , the effect of the dams was obscured by the effects of drought, hunting, and human use.

In 1983, plant growth in most places was much less luxuriant than it had been before impoundment. Bird populations seemed much smaller than formerly, and populations of at least some ungulates had declined. The most abundant ungulate, the Lechwe (Kobus leche), is reported to have declined by about half in the last eight years.

The lower dam has diverted all flow from parts of the Kafue channel below the Flats, presumably destroying aquatic communities there, while the reservoir of the upper dam has inundated some of the best wildlife habitat in Kafue National Park. Long-term effects of the dams on the biological and human communities of the region are still not clear.

\section{REFERENCES}

Balasubrahmanyam, S. \& Abou-Zeid, S. M. (1982). The Kafue River hydroelectric development. Pp. 31-3 in Howard \& Williams (q.v.).

Bell, R. H. V., Grimsdell, J. J. R., Lavieren, L. P. van \& Sayer, J.A. (1973). Census of the Kafue Lechwe by a modified method of aerial stratified sampling. E. Afr. Wildl. J., 11, pp. $55-74$.

Chapman, D. W., Miller, W. H., Dudley, R. G. \& Scully, R. J. (1971). Ecology of fishes in the Kafue River. FAO FI:SF/ Zam 11: Tech. Rep. (Rome), 2, 66 pp.

DHV Consulting EngineERs (1980). Kafue Flats hydrological studies, final report. Zambia Min. Agric. and Water Devel., Lusaka, Zambia [not available for checking].

DouthwaITe, R. J. (1974a). An endangered population of Wattled Cranes (Grus carunculatus). Biol. Conserv., 6, pp. 13442.

Douthwaite, R. J. (1974b). The ecology of Ducks (Anatidae) on the Kafue Flats, Zambia. Final Report to the Kafue Basin Research Committee, University of Zambia, Lusaka, Zambia: 103 pp. (mimeogr.).

DouthwaITE, R. J. (1982). Waterbirds: Their ecology and future on the Kafue Flats. Pp. 137-40 in Howard \& Williams (q.v.).

Douthwaite, R. J. \& Lavieren, L. P. van (1977). A description of the vegetation of Lochinvar National Park, Zambia. Nat. Coun. Sci. Res. Tech. Rpt (Lusaka), 34, 66 pp.

DudLeY, R. G. \& SCull.y, R. J. (1980). Changes in experimental gill-net catches from the Kafue Floodplain, Zambia, since construction of the Kafue Gorge Dam. J. Fish. Biol., 16, pp. $521-37$.
FAO (1968). Multipurpose Survey of the Kafue River Basin, Zambia. FAO/SF: 35/ZAM, Rome, Italy: 7 vols.

Handlos, D. M., Handlos, W. L. \& Howard, G. W. (1976). A study of the diet of the Kafue Lechwe (Kobus leche) by analysis of rumen contents. Pp. 197-211 in Proc. Fourth Regional Wildlife Conf. East. Cent. Africa. (Dept of National Parks and Wildlife Service, Lusaka, Zambia.) [Not available for checking.]

HandLOS, W. L. (1982). Introduction to the ecology of the Kafue Flats. Pp. 5-29 in Howard \& Williams (q.v.).

Howard, G. W. \& JefFery, R. C. V. (1981). Present distribution of Lechwe on the Kafue Flats. Black Lechwe No. 1 NS, pp. 17-20.

Howard, G. W. \& Jeffery, R. C. V. (1983). Kafue Lechwe Population Status, 1981-1983. A report to the Director, National Parks and Wildlife Service, Lusaka, Zambia: 12 pp. (mimeogr.).

Howard, G. W. \& Williams, G. J. (Eds) (1982). Proceedings of the National Seminar on Environment and Change: The Consequences of Hydroelectric Power Development on the Utilization of the Kafue Flats, Lusaka, April 1978. Kafue Basin Res. Comm., University of Zambia, Lusaka, Zambia: 159 pp.

Kushlan, James A., OGden, J. C. \& Higer, A. L. (1975). Relation of water level and fish availability to Wood Stork reproduction in the southern Everglades, Florida. U.S. Geol. Surv. Open File Rpt 75-434, 56 pp.

Lagler, K. F., Kaptezki, J. M. \& Steward, D. J. (1971). The Fisheries of the Kafue River Flats, Zambia, in Relation to the Kafue Gorge Dam. FAO FI:SF/Zam 11 :Tech. Rep. (Rome), $1,161 \mathrm{pp}$.

Muyanga, E. D. \& Chipundu, P. M. (1982). A short review of the Kafue Flats fishery, from 1968 to 1978. Pp. 105-13 in Howard \& Williams (q.v.).

OsBorne, T. O. (1973). Additional notes on the birds of the Kafue Flats. $P u k u, 7$, pp. 163-6.

ReEs, W. A. (1978a). The ecology of the Kafue Lechwe. J. Appl. Ecol., 15, pp. 163-217.

ReES, W. A. (1978b). Do the dams spell disaster for the Kafue Lechwe? Oryx, 14, pp. 231-5.

RobinetTe, W. L. \& CHILd, G. F. T. (1964). Notes on the biology of the Lechwe (Kobus leche). Puku, 2, pp. 84-117.

SAYER, J. A. \& Lavieren, L. P. VAN (1975). The ecology of the Kafue Lechwe population in Zambia before the operation of hydroelectric dams on the Kafue River. E. Afr. Wildl. J., 13, pp. 9-38.

SCHUSTER, R. H. (1976). Lekking behavior in Kafue Lechwe. Science, 192, pp. 1240-2.

SCHUSTER, R. H. (1980). Will the Kafue Lechwe survive the Kafue dams? Oryx, 15, pp. 476-89.

SHEPPE, W. A. (1972). The annual cycle of small-mammal populations on a Zambian floodplain. J. Mammal., 53, pp. 44560.

ShePpe, W. A. (1973). Notes on Zambian rodents and shrews. Puku, 7, pp. 176-90.

ShePpe, W. A. \& Osborne, T. O. (1971). Patterns of use of a floodplain by Zambian mammals. Ecol. Monogr., 41, pp. 179-205.

Williams, G. J. \& Howard, G. W. (Ed.) (1977). Development and Ecology in the Lower Kafue Basin in the Nineteen Seventies. Kafue Basin Res. Comm., University of Zambia, Lusaka, Zambia: 99 pp. 